\title{
Research on New Teaching Model of College English Integrated with Mobile Learning
}

\author{
Bao Songbin \\ College of Foreign Language \\ Northeast Electric Power University \\ Jilin City, Jilin, China \\ baosongbin@163.com
}

\begin{abstract}
College English in China usually adopts the form of large-scale class teaching, and its effect is not satisfying as expected. In order to improve the effectiveness of College English teaching, this paper proposes a new teaching model that integrates mobile learning (M-learning). It first analyzes the difficulties faced by Chinese College English teaching, and then gives some corresponding strategies. On this basis, the paper searches for the application software that can meet the needs of College English M-learning, and then designs a teaching model that is complementary to College English in-class teaching. Practice has shown that this teaching model is capable of increasing the amount of study time and improving the study efficiency objectively, and it is welcomed by College English teachers and students.
\end{abstract}

Keywords-College English; Mobile learning; Teaching environment; Learning strategy; Application software

\section{INTRODUCTION}

In China, College English is usually a compulsory course in universities, which covers a long time to learn, in general 4 semesters. Due to the limitation of resources such as teachers, classrooms and equipments, College English teaching is usually carried out in large-scale classes with more than 70 students. Many studies have shown that the teaching effect of College English is negatively related to class size, and the excessive class size inevitably has some adverse effects on teaching quality [1]. This is mainly due to the fact that the average time and opportunity provided for learners' language practice in large-scale classes is relatively reduced with the increase in the number of students. Therefore, students' learning passion and College English teaching quality will unavoidably be affected.

Fortunately, with the popularity of smart phones and wireless networks, a new M-learning model is emerging [2]. This learning model can enhance teacher-student interaction, stimulate interest in learning and improve teaching efficiency, thus making up for the shortage of College English teaching in large-scale classes. In this article, we will introduce a College English teaching model that integrates M-learning. The following arrangements are as follows: the second section analyzes the main problems in Chinese College English teaching; the third section investigates the basis of M-learning and attempts to give some coping strategies; the fourth section utilizes a mobile APP, "superstar learning link", to design a new College English teaching model with the integration of Mlearning, thus breaking the limitation of time and space between students and teaching resources; the fifth section gives practical results; and the last section is the conclusion.

\section{Problems FACEd By College English TeACHING}

Based on the analysis of the existing literature and our teaching experience, the main problems of College English teaching in China can be summarized as follows [3-8]:

(1) Teachers don't pay enough attention to individual students. Every teacher expects students to have a good learning attitude, a high interest in learning and good grades. This requires teachers to master students' personal learning and give appropriate guidance. However, due to the large number of students in large-scale classes, it will take teachers a long time to be familiar with the whole class. At the same time, due to the large number of students, the opportunity and time for speaking are correspondingly limited. These reasons lead to a reduction in teacher-student face-to-face communication, lower rates in questioning and task detection. Therefore, it is difficult to file detailed student information and establish a harmonious teacher-student relationship.

(2) Students' English level in one class is uneven. Before entering the university, students usually have 9-year English learning experience, which has led to their different English proficiency. Therefore, their capability to probe into the depth and the content of English knowledge is different. In this case, even if teachers have a full understanding of the students and take into account the students' differences, it is impossible to fully meet the different needs of the students and also difficult for most English teachers to grasp the teaching intensity and the teaching progress.

(3) There is a lack of effective interaction in the classroom. There are some problems in the interaction of College English classroom: (1) Teachers take the dominant position in the classroom, while students listen to the class passively, which is not conducive to students' full participation in the lessons.(2) Due to the large number of classroom participants, whether discussion or performance, such classroom interaction will take up plenty of time. (3)Because of shyness, students' enthusiasm for participating in classroom interaction is not enough.(4) It is 
difficult to keep the discipline in the process of classroom interaction. In a word, large-scale class teaching makes it impossible for teachers to take care of every student, so that students who have poor English proficiency and introverted character are easily ignored, which will inevitably contuse their enthusiasm for learning and result in depression and unintentional listening.

(4) The teaching method and the teaching environment need to be improved. Both traditional methods and multimedia usage adopt a single teaching approach in College English teaching. Traditional teaching is still the one with teaching materials, blackboards, chalks, teachers, and lectures available. Even with the application of multimedia teaching facilities, the screen is often regarded as a substitute for blackboard, lacking image interest and creativity. Due to big-size classrooms, students sitting in the back rows often complain that they can't see or hear clearly. Since the courseware speed and rhythm played by College English teachers are not appropriate, it is unlikely for students to keep up with the recording pace.

\section{ADVANTAGES OF M-LEARNING}

M-learning is based on the current relatively mature wireless mobile network and multimedia technology with the support of mobile phones, PAD and other wireless devices, to carry out interactive teaching and learning activities between teachers and students in order to improve the flexibility and convenience of teaching and strengthen the communication between teachers and students, students and students, science and technology [9-10]. In recent years, the combination of Mlearning and College English teaching has gradually increased (Figure 1), which shows that M-learning has already had a good foundation and application prospects.

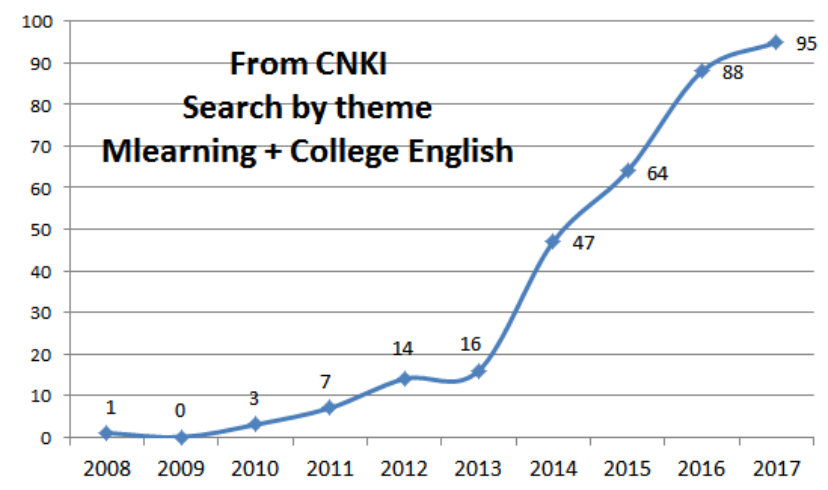

Fig. 1. The Number of Papers Published in College English M-learning

The advantages of M-learning are mainly reflected in the following aspects:

(1) It is not limited by time and space. In the course of learning, students can immediately log in to Internet enquiries or ask teachers questions once they encounter problems. This strengthens the interaction between teachers and students and facilitates teachers to get feedback in time and understand the current situation of students' individual learning.

(2) It is autonomous learning which is easy to individualize. Under the support of M-learning, students can choose suitable learning content and learning methods in terms of their actual needs, and can better realize self- management and supervision, thus improving their learning initiative and enthusiasm.

(3) It is a rich interactive form. M-learning enables teachers and students to exchange and discuss at anytime and anywhere. The medium of interaction can be SMS, MMS, call, video and so on. The interactive form can be 1 to 1,1 to many, many to many. Both voice and image can be clearly and accurately received by students.

Although M-learning has a lot of advantages compared to traditional classes, students still need teachers' guidance in the process of M-learning according to our survey (see the fifth section). Therefore, only by using some teaching strategies to integrate the traditional classes with M-learning effectively can the role of M-learning be fully played, so as to improve the effect of College English teaching. For example, teachers should provide teaching resources and learning tasks that match the course schedule; teachers should supervise the students' M-learning and feedback their opinions in time; teachers should change the teaching methods and teaching contents according to the effect of M-learning. Such timeconsuming works as naming, report, oral practice, writing practice can be fulfilled by means of M-learning software.

\section{THE NEW TEACHING Model of COLLEGE ENGLish}

In order to integrate M-learning with traditional classes, it is not adequate to use some strategies only. It also needs to use the application software to establish a College English Mlearning environment. In the existing researches, many teachers use WeChat as a platform to carry out M-learning [3]. Although some results have been achieved, WeChat, as a common instant chat tool, does not have some necessary teaching functions, such as tests. Therefore, WeChat has not been selected as the research platform. Through investigation, we have adopted a special M-learning APP, “superstar learning link" as the research platform. ${ }^{1}$

\section{A. Functional Modules of the Application Software}

"Superstar learning link" is launched by superstar network, and the client is M-learning platform for mobile terminals, such as smart phones and PAD. Students can download and install the original search app by opening the App Store (Android) or App Store (Apple) in the phone. "Superstar learning link" has many functional modules such as learning, interaction, reading, study and social interaction.

(1)Learning function: After logging in, you can enter the course and find the courses set in "My Course" to learn the professional contents. On the platform of "superstar learning link", students can preview/review teaching contents, strengthen and connect learning knowledge in order to broaden their learning contents.

(2)Interactive function: Click on the curriculum, enter the curriculum interface, and create a new class in the course management. Each class has its own two-dimensional code and invitation code. By inputting invitation code or sweeping the

\footnotetext{
${ }^{1} \mathrm{Http}$ ///app.chaoxing.com/
} 
two-dimensional code, you can join the class. Click on the corresponding class, you can select, teach, answer, broadcast, sign in, distribute questionnaires, publish controls, etc.

(3)Reading function: Unlike the previous PC terminal communication, "superstar learning link" is more convenient. Students can take advantage of fragmented time, carrying out reading on smart phones and PAD and other mobile terminals, self-helping library collection, downloading electronic resources and browsing the latest information. "Superstar learning link" contains a million copies of electronic books, newspaper articles and literature metadata and can provide mobile teaching services to teachers and students easily. With the help of the APP, students can subscribe to interested contents, classify and manage knowledge, achieve effective sharing of resources.

(4) "Study" function: The resources in "superstar learning link" are abundant, including books, periodicals, newspapers, lectures and a series of contents. Students can use the resources to self-establish personal "study" to achieve the collection of books and articles for their own study, such as: online reading, taking notes, writing special topics and other forms of activities.

(5)Social function: "Superstar learning link" can set up professional discussion groups, which are targeted at students with the identical interest and ambition. In similarity to QQ group or WeChat group, there are a number of functions such as dialogue, signing, answering, questionnaire, red packet, and broadcast merits in "superstar learning link".

\section{B. The New Teaching Model}

The new teaching model based on "superstar learning link" must be guided by College English teachers and characterized by student-focused orientation, which should actively mobilize students' initiative and consciousness, strengthen the interaction between teachers and students and the interconnection among various teaching resources and create an equal, enlightening, sharing, interactive environment in the course of College English teaching. Such a cooperative and harmonious teaching environment can not only break the constraints of time and space in the traditional teaching model but also reform traditional teaching methods. With the help of M-learning platform, effective interaction between teachers and students, students and students in College English teaching can be realized, so as to enhance students' learning enthusiasm and initiative.

Prior to class, a notice is sent through "superstar learning link" to require students to read the teacher's messages. "Superstar learning link" can push the related reading materials intelligently and students can create specific knowledge topics according to the learning function. In order to ensure the study effect and fulfill the monitoring role of "superstar learning link", College English teachers must supervise the learning circumstances in "superstar learning link", such as setting up "drag and drop prevention" for audio, video and other visual data, interspersing questions in the recording, and carrying out a small amount of tests after reading is completed. Then, the platform will send the learning results to teachers, who can acquaint themselves with the students' mastery level of main knowledge points according to the statistical data, thus effectively adjusting the teaching interaction in the class. When using "superstar learning link" to conduct online teaching, teachers can sign in to check attendance by means of signing codes. In the "interactive classroom" mode of the menu bar, teachers can choose to communicate with students in different forms, such as video chat, conference, seminar, etc., to dissolve the difficult knowledge points in students' learning process and give guidance and feedback.

In class, teachers can open the function of barrage and randomly answer students' questions through Mobile Phone Total Control, and even send red packets on the spot to fully mobilize the enthusiasm of students.

After class, some interesting questions related to learning content can be designed for students to think and discuss. Teachers can comment on students' discussion appropriately. Students can also ask questions about the words, sentence patterns and contents in the study, and the whole class will discuss and share their opinions together. Students can also take the initiative to participate in the selection and induction of the choice of English materials, such as the classification of vocabulary, the analysis and application of text structure, reading training, and appreciation of literary works. The material selected can be relevant texts, pictures, animation, audio, video and other forms of media. This inquiry learning method sets up a bridge to help learners transfer from receptive learning to autonomous learning, help students to change their way of learning and assist students to experience and internalize various views in the process of College English learning. "Superstar learning link" can analyze the data in the course of learners' participation in the learning process, excavate the potential learning interest and learners' mastery of knowledge and recommend the helpful materials for learners in their further study.

\section{PRACTICAL RESUltS}

Our target group was a total of 1,510 students enrolled in 2017. Before carrying out the practice of teaching reform, we investigated the conditions for students' online learning and their willingness to participate in this teaching reform experiment. $75.1 \%$ were willing to take part in, while $24.9 \%$ did not want to participate. Since this experiment was based on the normal class, it was impossible to exclude those who did not want to participate. $95.2 \%$ of the subjects (1,438 people) had smartphones (Figure 2), most of which were over 1GB (Figure 3) and $66.62 \%(27.75 \%+38.87 \%)$ of the subjects surfed the Internet for more than 1 hour every day (Figure 4). The analysis mentioned above has shown that we have the subjective and objective conditions for developing M-learning practice.

We utilized the application software and the teaching model mentioned in the fourth section to carry out the teaching procedure. After one year, students' spare time for learning English has increased significantly (Figure 5). Among them, the number of students learning less than 20 minutes a day dropped from $64.7 \%$ to $37.42 \%$. The proportion of students who studied for more than 40 minutes increased from $10.27 \%$ to $17.68 \%$. This illustrates that students' learning initiative and enthusiasm have been improved, which are both the foundation 
of improving English level. There were two tests during the experimental period. The first one was done in the 4th month after the experiment was implemented, and the second one was done in the 10th month after the experiment was carried out. From the examination results, the overall average score of the practical class, with the lower failure rate (Figure 6 and 7), was slightly higher than that of the non-experimental class. This shows that our teaching model has really improved the teaching effect. The survey also shows that $84.1 \%$ of students hold the opinion that $\mathrm{M}$-learning has played a positive role in improving English level. In addition, most students' Mlearning was attended by teachers (Figure 8). This demonstrates that our strategy of using "superstar learning link" to enhance teachers' guidance for students' M-learning is in accordance with demand.

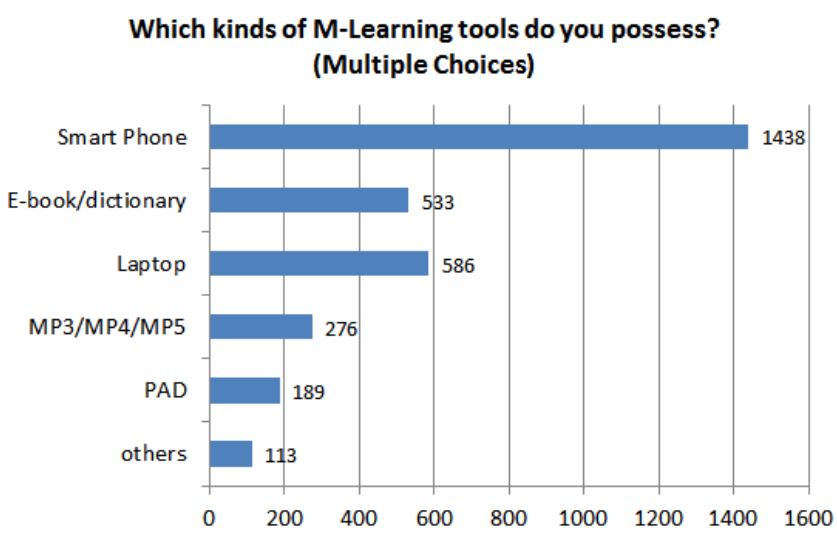

Fig. 2. Students' Possession of M-learning Tools

\section{The data flow each month}
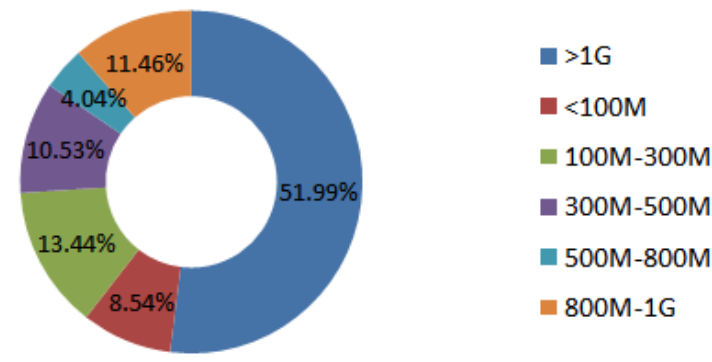

Fig. 3. Data Flow of Students' Smart Phone

\section{The time online every day}

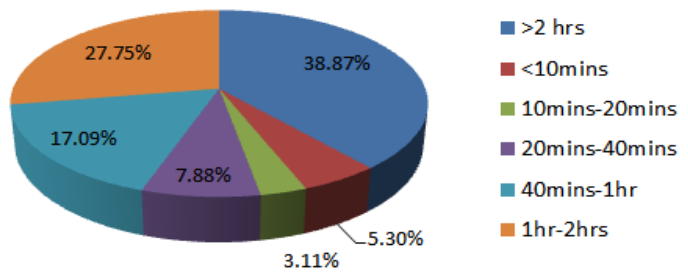

Fig. 4. Students' Online Time

\section{The time spand on college english m-learning everyday}

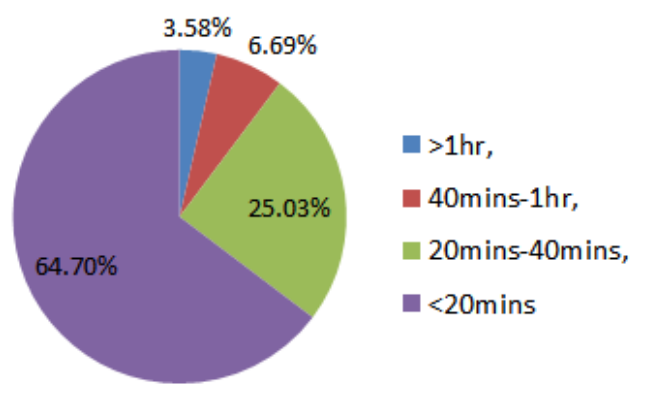

(a) Before the Experiment

\section{The time spand on college english m-learning everyday}

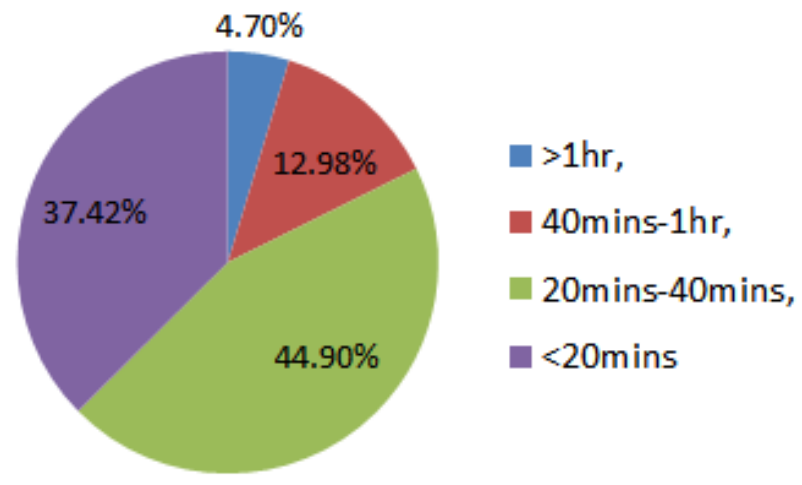

(b) After the Experiment

Fig. 5. Time Comparison Spent by Students to Learn English After Class

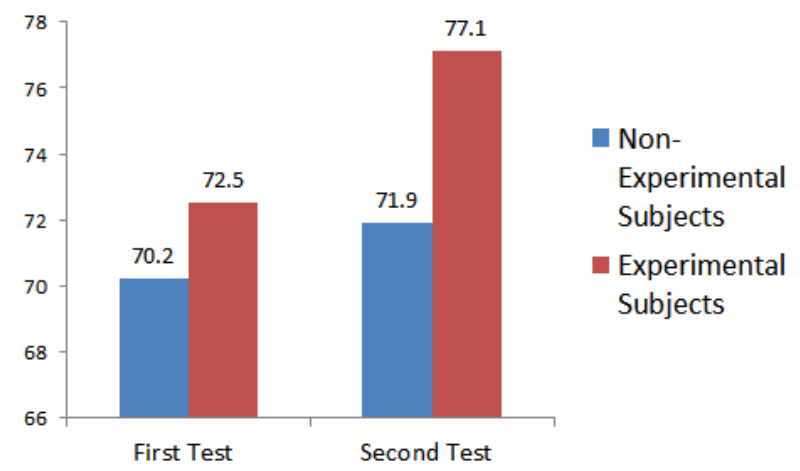

Fig. 6. Comparison of Students' Average scores 


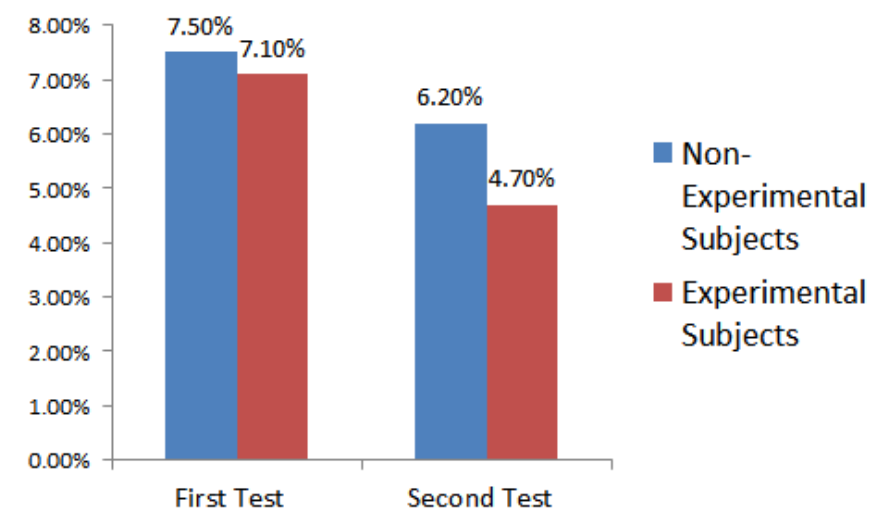

Fig. 7. Comparison of Students' Failure Rates

\section{CONCLUSION}

College English teaching in large-scale classes will affect the teaching quality. In view of this problem, this paper studies a new teaching model of College English that integrates with M-learning. This model takes "superstar learning link" as the platform, and closely links traditional classroom with extracurricular teaching. The practice shows that, compared with traditional College English teaching, the new teaching model not only breaks the limitation of time and space, but also realizes the colorful and changeable interactive teaching at anytime and anywhere through mobile terminal. The new model not only improves students' learning initiative and interest but also further enriches teaching methods and teaching model, making College English teaching more flexible and more pertinent. This new model is also a beneficial supplement to traditional College English teaching and further improves the teaching quality and efficiency. Still, a small number of students do not like the teaching model that integrates Mlearning (Figure 6). As some students say, "Learning is his own business. If it is limited, he never wants to learn." Therefore, it is worthy of further discussing how teachers can effectively supervise and guide the students' M-learning and endeavor to avoid students' feeling that their learning has been monitored.

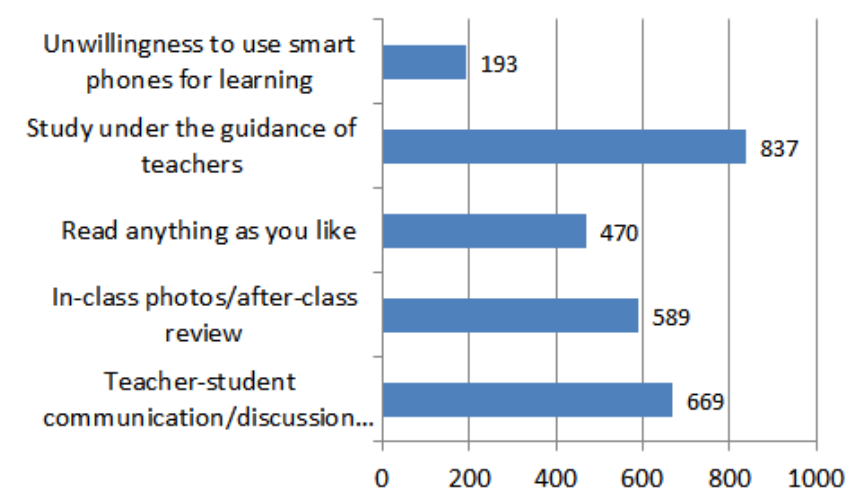

Fig. 8. Students' favorite form of college English mobile learning

\section{ACKNOWLEDGMENT}

This work is supported by the following projects: the "13th Five-Year" Social Science Project (JJKH20170117sk) of the Jilin Provincial Education Department; the Teaching Reform Project (JX201617) of Northeast Electric Power University; and the Graduate Education and Teaching Reform Research Project (YJG201704) of Northeast Electric Power University.

\section{REFERENCES}

[1] Zhang X, Bi J. Design of a College English Mobile Learning System Based on CAD Model[J]. International Journal of Emerging Technologies in Learning (iJET), 2018, 13(04): 139-149.

[2] Liu T Y. Developing an English mobile learning attitude scale for adult learners[J]. Journal of Educational Technology Systems, 2017, 45(3): 424-435.

[3] Jin W, Zhirui D. Research on Mobile Learning Model of College English Based on WeChat Platform[J]. Eurasia Journal of Mathematics, Science \& Technology Education, 2017, 13(8): 5847-5853.

[4] Thornton P, Houser C. Using mobile phones in English education in Japan[J]. Journal of computer assisted learning, 2005, 21(3): 217-228.

[5] Chang C C, Liang C, Yan C F, et al. The impact of college students' intrinsic and extrinsic motivation on continuance intention to use English mobile learning systems[J]. The Asia-Pacific Education Researcher, 2013, 22(2): 181-192.

[6] Shih R C. Can Web 2.0 technology assist college students in learning English writing? Integrating Facebook and peer assessment with blended learning[J]. Australasian Journal of Educational Technology, 2011, 27(5).

[7] Lu M. Effectiveness of vocabulary learning via mobile phone[J]. Journal of computer assisted learning, 2008, 24(6): 515-525.

[8] Huang L. Acceptance of Mobile Learning in Classroom Instruction among College English Teachers in China Using an Extended TAM[C]//Educational Innovation through Technology (EITT), 2017 International Conference of. IEEE, 2017: 283-287.

[9] Wang M, Shen R, Novak D, et al. The impact of mobile learning on students' learning behaviours and performance: Report from a large blended classroom[J]. British Journal of Educational Technology, 2009, 40(4): 673-695.

[10] Chang C C, Yan C F, Tseng J S. Perceived convenience in an extended technology acceptance model: Mobile technology and English learning for college students[J]. Australasian Journal of Educational Technology, $2012,28(5)$. 